\title{
Tax Planning and Firm Value: Evidence from Malaysia
}

Mohd Waliuddin Mohd Razali, Siti Shahfina Ghazali, Janifer Lunyai and Josephine Yau Tan Hwang

To Link this Article: http://dx.doi.org/10.6007/IJARBSS/v8-i11/4896

DOI: 10.6007/IJARBSS/v8-i11/4896

Received: 19 Sept 2018, Revised: 23 Oct 2018, Accepted: 06 Nov 2018

Published Online: 25 Nov 2018

In-Text Citation: (Razali, Ghazali, Lunyai, \& Hwang, 2018)

To Cite this Article: Razali, M. W. M., Ghazali, S. S., Lunyai, J., \& Hwang, J. Y. T. (2018). Tax Planning and Firm Value: Evidence from Malaysia. International Journal of Academic Research in Business and Social Sciences, $8(11), 210-222$.

\section{Copyright: (C) 2018 The Author(s)}

Published by Human Resource Management Academic Research Society (www.hrmars.com)

This article is published under the Creative Commons Attribution (CC BY 4.0) license. Anyone may reproduce, distribute, translate and create derivative works of this article (for both commercial and non-commercial purposes), subject to full attribution to the original publication and authors. The full terms of this license may be seen at: http://creativecommons.org/licences/by/4.0/legalcode

Vol. 8, No. 11, 2018, Pg. 210 - 222

Full Terms \& Conditions of access and use can be found at http://hrmars.com/index.php/pages/detail/publication-ethics 


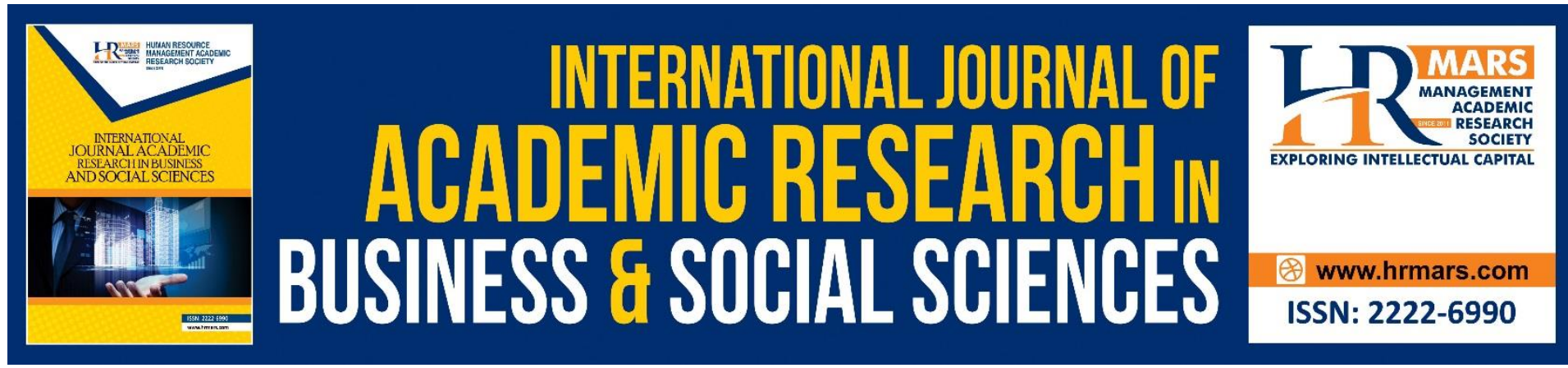

\title{
Tax Planning and Firm Value: Evidence from Malaysia
}

\author{
Mohd Waliuddin Mohd Razali, Siti Shahfina Ghazali, Janifer \\ Lunyai and Josephine Yau Tan Hwang \\ Faculty Economics \& Business, Universiti Malaysia Sarawak (UNIMAS) \\ 94300 Kota Samarahan, Sarawak, Malaysia. \\ Email: walirazali@yahoo.com,mrmwaliuddin@unimas.my
}

\section{ABSTRACT}

The main objective of this study is to determine the impact of tax planning on firm value of firms listed in Bursa Malaysia. Tax planning proxies in this study are the Effective Tax Rate (ETR) and Book Tax Differences (BTDs). The 387 samples data were collected from the DataStream from period of 2014 to 2016. After controlling the firm size, leverage, asset tangibility, firm age and dividend, the regression results show that ETR has a significant and positive relationship with firm value while BTDs has insignificant negative relationship with firm value. Firm with less tax planning activities may signal investors that the firm is more transparent in publishing their financial information. Most of our control variables such as leverage, asset tangibility, firm age and dividend have negative relationship with firm value. This study suggests that ETR proxy is suitable to determine firm value rather than BTDs. For future research, this study can be expanded by using more sample size from a longer time frame of research.

Keywords: Tax Planning, Firm Value, Effective Tax Rate, and Book Tax Differences

\section{Introduction}

Tax is one of the major instruments of fiscal policy that is known to regulate the economy of any country in the world. As viewed from part of either theoretically or empirically, both provide famously known results which prove that tax is giving a big contribution to determine the capital structure of firms situated in all the nations. For instance, an instrument namely tax policy has been elected in order to stimulate the growth of private sector in the field of mainly industrial and corporate growth.

Usually a firm will try to make tax planning optimization in order to enhance the income after tax. "Tax planning consists in minimizing mainly the income tax in order to maximize the result after taxes" (Soufiene Assidi et al, 2016). A firm with good profit margin will increase the reputation of that particular the firm. Besides, other main purpose of tax planning is to create a firm's value and link this directly to quality of firm's managerial organization and planning. Managers will usually find a way to minimize their tax burden so that they would be able to gain tax benefits after tax returns or shareholder wealth. 
Tax planning has been a vital weapon to alleviate the effect of tax on liquidity and profitability of firms. Effective Tax Rate (ETR) measures the firm's tax burden and can also look through the performance of a firm. Increase in the profitability level of a firm will signals investors that the firm value is good and will attract more investors to invest. This is because the investors might know the firm has higher profitability by paying lower tax rate and able to provide higher return for their shareholders.

In the context of Malaysia, the Malaysian government has readily sketched various tax incentives in order to inspire the firms available in Malaysia. Common tax rate in year 2016 of a firm is set at a benchmark up to $24 \%$. So with tax incentives, firms can increase their aftertax return by paying less for corporate tax. The Malaysian Government is also trying their best to reduce the tax rate over the years in order to ease investors and also attract them to invest more. One of the incentives given by the Malaysian government is Pioneer Status. Under Pioneer Status, this incentive reduces the amount of taxable income. So, eventually the ETR of the firm will also be low. Thus, such incentive will increase the interest of local as well as foreign investors to invest more in Malaysia.

Diagram 1.1 Firm Tax Rate in Malaysia

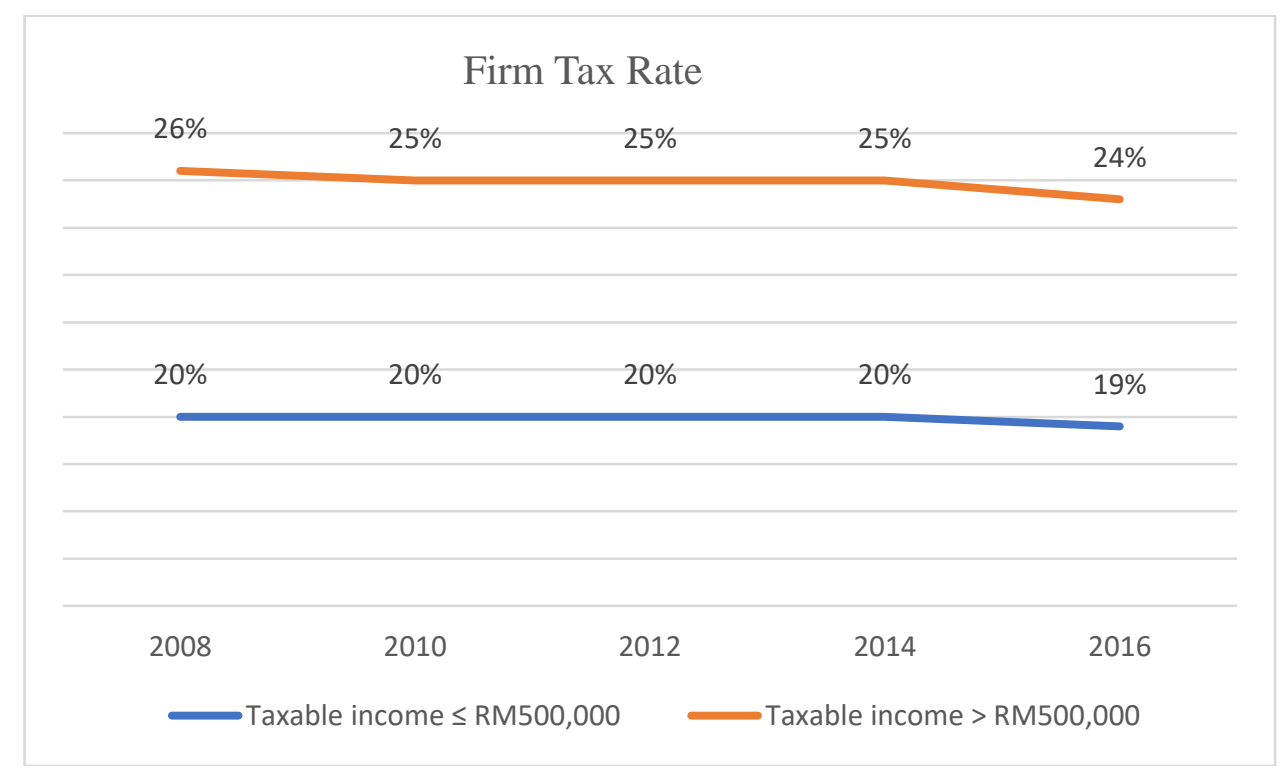

Besides, Reinvestment Allowance (RA) is also given by Malaysian government to those firms that would like to reinvest in order to expand, modernising or automating their business. RA allows the firms to expand their operation without incurring high expenses. Foreign investors would favour such incentive because they can invest in bigger firms in to get higher returns. Next, our government also gives tax exemption on value increase of exports. This means foreign country can import Malaysian's product to their country at a lower cost. This will result in firms with tax shield having higher sales and those firms are most preferred by foreign investors to invest. They will also value the firms more since they get a higher return from their investment in our country, without facing any default.

Anyhow, topics on tax planning and market capitalization related to firm value have not brought any clear view to the public until today. Hanlon and Heitzman (2010) have drawn a conclusion from their research which says the relationship between tax optimization and firm value remained unclear. Sometimes, tax planning can also cause the firm value to decrease 
when managers tend to either take chance to understate reported accounting income and this will pull down the firm value causing the share price of the firm to reduce over time. They might think understating accounting income is a chance but investors value the firm from that income statement. Lower income will reflect that the firm is doing bad and would not be able to pay their shareholders properly.

Many past researchers used effective tax rate (ETR) as tax planning proxy. There are growing recent literatures using book tax differences (BTDs) as other tax planning proxy (e.g.: Desai \& Dharmapala, 2009, Wilson, 2009, Martinez \& Ronconi, 2013). BTDS provide a signal regarding the informativeness earnings such as of persistence and growth pre-tax income. Therefore, this study used both ETR and BTDS as tax planning proxies to determine the impact the on firm value of firms listed in Bursa Malaysia.

\section{Literature Review}

Signalling theory is beneficial to explain behaviours between two parties that get access to different types of information. According to Spence (1974), he defines market signals as the travel of information to other people in the market environment regarding some unobserved activity. Signalling theory can actually reduce agency costs and information asymmetry between firms and market. Firms disclose information including disclosure of information related to tax lies somewhere among no disclosure and full disclosure, depending on motivations. These motivations actually differ and have significant effect on level of disclosure among the firms and also varies from one territorial to another (Premuroso, 2008). Almost every or at least half number of firms available would like to publish information regarding their business forecast so that to signal whether they have or not good investment opportunities. Firms that have been identified good investment opportunities based on the valuable information given by them which can attract many investors to buy their shares. This will eventually increase their share price and firm's value over time.

In an efficient market hypothesis, all needed information is really and quickly updated in a security's market price, and therefore it just predicts that all the investors will get an equilibrium rate of return. Just to put it in another way, an investor should not expect getting a return higher than the market, either fundamentally or through technical analysis. In relation to this study, firms need to be really sure about the technique they use for tax planning. Aggressive tax planning can bring down the reputation of a firm. So, this will signal bad intuition to the investors causing them to lose interest in investing in that firm. Besides, if the firm was accused to be applying fraud techniques and was charged by the court, then the case might signal investors that the firm is involved in aggressive tax planning method which could lead to higher cost and prosecution.

Researches regarding tax planning and firm value so far have generated mixed results. In research made by Desai and Hines (2002) related to firm performance and tax planning behaviour of firms, they found that comprehensive tax planning in term of foreign tax credit can increase firm performance and together with firm value. In Desai and Dharmapala (2005) research, they knew a positive correlation between tax plan and well-governed firm's performance, and concluded that in tax planning and firm performance study it is being arbitrated by corporate governance. Tax planning is measured by inferring the difference between the income reported to capital markets and tax authorities (the book-taxgap).Having reduced tax cost in legal manner will signal to investors that the firm is trying its best to reduce the expenses while increasing the income so that it may pay higher dividend to the shareholders. This will eventually increase the firm value. Despite, some researcher 
such as Abdul Wahab and Holland (2012) said that there is negative relationship between tax planning and firm value despite the existence of corporate governance. They used ETR to measure tax planning.

Another study was carried out by Desai and Dharmapala (2009) to investigate the relationship between tax planning, corporate governance and firm's performance. In their study, they used Tobin's $Q$, governance quality and book tax gap as their proxy. The study claimed that book tax gap has almost no effect on the firm performance. However, there is a positive relationship between tax planning savings and value of well governed firms. So, in the end they conclude it as corporate governance is needed to assist the performance of firm that adopt tax planning.

Besides, Wilson (2009) has also conducted a research to test the impact of tax shelter measure involvement through financial reporting on book tax difference of tax shelter in the invention of wealth for shareholders. The tax shelter proxy was measured by using the profile information of US firm accused tax shelter. The end result revealed that those firms that are well governed as well as actively participating in tax shelter activities gets strange positive return. This result is somehow in line with the theory saying that tax shelter could be used for generating revenue in well governed firms. Desai and Dharmapala (2009) also shared the theory who has postulated that tax planning can have more positive influence on well governed firms as compared to badly governed firms. This can be further supported by Morey et al (2009) where he found that enhancement in corporate governance can lead to increment in firm value in emerging market.

Despite of positive relationship, there are also some negative relationships between tax planning and firm value discovered in prior studies. Ftouhi et al. (2014) tested whether firm tax planning could rise the firm value. ETR proxy was used in their study. The study result found that there is significant negative and relationship between tax planning and firm value because of too much agency cost. This result is linear to the shareholder's worry regarding principle threat in tax. Furthermore, this study also finds that tax planning can drive towards permanent tax savings. On the other hand, Chen et al. (2013) found out in his research that tax planning can rises agency cost and decrease firm value. They use both ETR and book tax difference as their tax planning proxies and it concluded that tax planning is not necessarily to increase firm value only.

Also, it has been stated that negative relationship occurs between tax planning and firm value in research of Abdul Wahab (2010) because the study found out that the risk and cost exceeds the benefit from tax planning. Tax planning in the study was measured by firm's tax saving. At times, certain firms are not good in making tax planning. Therefore, the management of the firm will then employ tax experts in handling the tax planning for that firm. This will increase the firm's cost because they need to pay them more than ordinary employee's salary.

Accounting researchers have applied book tax gap or differences as tax planning proxy to test the firm income and plot of taxable income to give clue about the quality of corporate income. Huge book tax difference reflects future income problem and lower income quality (Hanlon \& Shevlin, 2005). The higher deferred tax costs can have a bad influence to say that there might be depreciating income quality. Hence, book tax difference can be a good measuring tool to grade firm value.

As one of tax planning formula, film's uses various rules among financial reporting and tax reporting which increases the gap between financial accounting earnings and taxable earning. There are actually two main objectives of corporate earnings (Hanlon \& Shevlin, 
2005). First is the corporate earning is used for financial reporting purposes and secondly for the usage of tax reporting. So because of the two different objectives, they decided to use those with high reported accounting income for the referral of shareholders and creditors whereas those with low reported taxable earning for boosting cash flow by reducing tax payments.

Based on the above literature review, there is a mixed evidence of the relationship tax planning and firm value, hence we hypothesized our study as follow:

$\mathrm{H}_{1}$ : There is relationship between tax planning and firm value.

\section{Methodology}

Sample

The sample for this study consists of about 387 firms listed in Bursa Malaysia in every sector period of 2014 to 2016 which covers 3 years. Certain sectors were excluded such as banking and insurance because these sectors are governed by different regulations. Data were collected from the data stream while sample with unavailable data will be excluded.

\section{Regression Model}

Multiple regression analysis is being used to evaluate the relationship among the independent variable which is tax planning and control variables such as leverage, asset tangibility, firm age, and dividend affect the dependent variable which is firm value. In this study, proxies for tax planning are Effective Tax Rate (ETR) and Book Tax Differences (BTDs) and the proxy for firm value is Tobin's $Q$. Therefore, the regression model of this study as follow: -

\section{Model 1:}

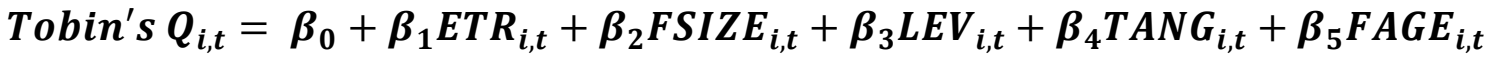

$$
+\beta_{6} D I V_{i, t}+\varepsilon_{i, t}
$$

\section{Model 2:}

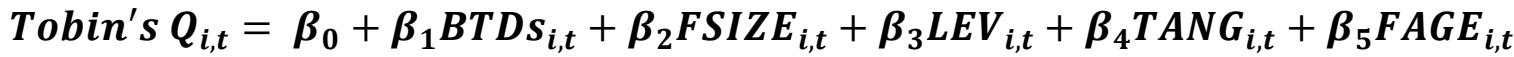

Where:

$$
+\beta_{6} D I V_{i, t}+\varepsilon_{i, t}
$$

$$
\begin{aligned}
& \text { ETR = Effective Tax Rate } \\
& \text { BTDs = Book Tax Difference } \\
& \text { FSIZE = firm size } \\
& \text { LEV = leverage } \\
& \text { TANG = tangibility of asset } \\
& \text { FAGE = firm age } \\
& \text { DIV = dividend } \\
& \beta=\text { coefficient } \\
& \varepsilon=\text { error term }
\end{aligned}
$$


INTERNATIONAL JOURNAL OF ACADEMIC RESEARCH IN BUSINESS AND SOCIAL SCIENCES

Vol. 8, No. 11, Nov, 2018, E-ISSN: 2222-6990 @ 2018 HRMARS

\section{Results and Discussion \\ Descriptive Statistics}

Table 1: Descriptive Statistics

\begin{tabular}{|l|r|r|r|r|}
\hline Variables & Minimum & Maximum & Mean & \multicolumn{1}{c|}{ Std. Deviation } \\
\hline Torbin's Q & .00 & .01 & .00 & .00 \\
\hline ETR & .00 & 40.06 & .3602 & 1.7715 \\
\hline BTDs & .00 & 6.85 & 6.61 & 4.68 \\
\hline FSIZE & .00 & 8.12 & 5.6916 & .8092 \\
\hline LEV & .00 & 0.7 & .1959 & .1585 \\
\hline TANG & .00 & 1169.56 & 68.9703 & 184.9959 \\
\hline FAGE & 1.00 & 188.00 & 25.3253 & 17.8359 \\
\hline DIV & -0.08 & 0.10 & .00 & .0042 \\
\hline
\end{tabular}

Based on the results shown earlier, the first variable is Tobin's $Q$, which represents the firm value and also the dependent variable of this study. Firm value of each firms, is measured by the division of total market value of the firm with the total asset of the particular firm. This variable has almost 0 mean (range from 0.00 to 0.01 ). Standard deviation for this variable is also 0. Second variable is Effective Tax Rate (ETR) one of the independent variables of this study. ETR can be calculated by dividing tax paid from earnings before interest and tax (EBIT). The average value for this variable is $36.02 \%$ (range from 0.00 to $40.06 \%$ ).Standard deviation for this variable is seems to be $177.15 \%$, which can be said is relatively large if compared to the mean value. The next independent variable is Book Tax Differences (BTDs). BTDs can be calculated by deducing estimate taxable income from earning before tax and then divide the value with the previous year's total asset of each firms. The average value for this variable is 6.61 times (range from 0.00 to 6.85 times. Standard deviation for this variable is seems to be 4.68 , which can be said is relatively small if compared to the mean value.

The fourth variable will be firm size (FSIZE), which can be computed using log to the total asset value of each firm. The mean for firm size is about 569.16 (range from 0.00 to 8.12). Standard deviation for this variable is 80.92 , which seems to be relatively small as compared to the mean value and also quite close to the mean value. Fifth variable in this study is the leverage (LEV), which can be calculated through the division of total debt from the total assets of each subsequent firm that have been used related in this study. The mean of leverage is $19.59 \%$ (range from 0.00 to 0.7 ). Standard deviation for this variable is 0.1585 , which is lesser than the mean value. The sixth variable in this study is the asset tangibility, which is calculated by dividing the non-current asset from the total asset of each firm. The mean of asset tangibility (TANG) is 68.97 times (range from 0.00 times to 1169.56 times). Standard deviation for this variable is 184.99 which seems to be too far and spread out from the mean value. The seventh variable will be the firm age, which is calculated by deducting the year since the firm begun to incorporate from the current year. The mean of firm age is 25.32 years (range from 1.00 year to 188.00 years). Standard deviation for this variable is 17.83 which is quite near to the mean and this shows that most of the data are closer to the mean value. The last variable in this study is dividend (DIV), which is calculated by dividing the dividend declared amount with the after tax earnings of each firm. The mean of dividend is $0.00 \%$ (range from $-0.08 \%$ to $0.10 \%$ ). Standard deviation for this variable is 0.42 which is quite far and spread out from the mean amount. 


\section{Pearson's Correlation}

In Pearson's correlation table, Torbin's Q has a significant negative relationship with FSIZE at the $10 \%$ level of significance but having LEV, FAGE and DIV the $1 \%$ of significance level. However, Torbin's $Q$ has a positive effect but not significant relationship with the TANG. ETR has positive effects but not significant relationship with the FSIZE and LEV. However, ETR has significantly negative relationship and with the TANG and BTDs at $5 \%$ and $1 \%$ significant level. Then, ETR shows significant positive relationship with FAGE and DIV at $5 \%$ and $1 \%$ respectively. BTDs has positive effects but not significant relationship with the FSIZE and FAGE. However, BTDs 
INTERNATIONAL JOURNAL OF ACADEMIC RESEARCH IN BUSINESS AND SOCIAL SCIENCES Vol. 8, No. 11, Nov, 2018, E-ISSN: 2222-6990 @ 2018 HRMARS

Table 2: Pearson's correlation

\begin{tabular}{|c|c|c|c|c|c|c|c|c|c|}
\hline & & Torbin's Q & ETR & BTDs & FSIZE & LEV & TANG & FAGE & DIV \\
\hline $\begin{array}{l}\text { Torbin's } \\
\text { Q }\end{array}$ & $\begin{array}{l}\text { Pearson } \\
\text { Correlation } \\
\text { Sig.(1-tailed) }\end{array}$ & 1 & & & & & & & \\
\hline ETR & $\begin{array}{l}\text { Pearson } \\
\text { Correlation } \\
\text { Sig.(1-tailed) }\end{array}$ & $\begin{array}{r}-0.0222 \\
0.597\end{array}$ & 1 & & & & & & \\
\hline BTDs & $\begin{array}{l}\text { Pearson } \\
\text { Correlation } \\
\text { Sig.(1-tailed }\end{array}$ & $\begin{array}{r}-0.0244 \\
0.563\end{array}$ & $\begin{array}{r}-0.245^{* * *} \\
0.000\end{array}$ & 1 & & & & & \\
\hline FSIZE & $\begin{array}{l}\text { Pearson } \\
\text { Correlation } \\
\text { Sig.(1-tailed }\end{array}$ & $\begin{array}{r}-0.0792^{*} \\
0.059\end{array}$ & $\begin{array}{r}0.0117 \\
0.781\end{array}$ & $\begin{array}{r}0.0389 \\
0.356\end{array}$ & 1 & & & & \\
\hline LEV & $\begin{array}{l}\text { Pearson } \\
\text { Correlation } \\
\text { Sig.(1-tailed }\end{array}$ & $\begin{array}{r}-0.2981^{* * *} \\
0.000\end{array}$ & $\begin{array}{r}0.0442 \\
0.293\end{array}$ & $\begin{array}{r}-0.0518 \\
0.293\end{array}$ & $\begin{array}{r}0.3877^{* * *} \\
0.000\end{array}$ & 1 & & & \\
\hline TANG & $\begin{array}{l}\text { Pearson } \\
\text { Correlation } \\
\text { Sig.(1-tailed } \\
\end{array}$ & $\begin{array}{r}0.0439 \\
0.295\end{array}$ & $\begin{array}{r}-0.0871^{* *} \\
0.038\end{array}$ & $\begin{array}{r}0.0951^{* *} \\
0.024\end{array}$ & $\begin{array}{r}-0.1653^{* * *} \\
0.000\end{array}$ & $\begin{array}{r}0.0407 \\
0.333\end{array}$ & 1 & & \\
\hline FAGE & $\begin{array}{l}\text { Pearson } \\
\text { Correlation } \\
\text { Sig.(1-tailed }\end{array}$ & $\begin{array}{r}-0.1683^{* * *} \\
0.000\end{array}$ & $\begin{array}{r}0.0869 * * \\
0.038\end{array}$ & $\begin{array}{r}0.0134 \\
0.750\end{array}$ & $\begin{array}{r}0.3129 * * * \\
0.000\end{array}$ & $\begin{array}{r}0.0343 \\
0.414\end{array}$ & $\begin{array}{r}-0.0282 \\
0.502\end{array}$ & 1 & \\
\hline DIV & $\begin{array}{l}\text { Pearson } \\
\text { Correlation } \\
\text { Sig.(1-tailed }\end{array}$ & $\begin{array}{r}-0.1397^{* * *} \\
0.001\end{array}$ & $\begin{array}{r}0.2566 * * * \\
0.000\end{array}$ & $\begin{array}{r}-0.0977^{* *} \\
0.020\end{array}$ & $\begin{array}{r}-0.3477^{* * *} \\
0.000\end{array}$ & $\begin{array}{r}-0.1445^{* * *} \\
0.001\end{array}$ & $\begin{array}{r}-0.6436 * * * \\
0.000\end{array}$ & $\begin{array}{r}-0.0752 \\
0.073\end{array}$ & 1 \\
\hline
\end{tabular}

${ }^{* * *}$. Correlation is significant at the 0.01 level (1-tailed), ${ }^{* *}$. Correlation is significant at the 0.05 level (1-tailed), and*. Correlation is significant at the 0.10 level (1-tailed). 
INTERNATIONAL JOURNAL OF ACADEMIC RESEARCH IN BUSINESS AND SOCIAL SCIENCES Vol. 8, No. 11, Nov, 2018, E-ISSN: 2222-6990 @ 2018 HRMARS

have significant negative relationship with the DIV at $5 \% \%$ significant level. Then, BTDs shows significant positive relationship with TANG at $5 \%$ significant level and negative effect with no significant relationship with LEV. FSIZE has shown a significant positive relationship with LEV and FAGE at $1 \%$ of significance level. However, FSIZE has significant negative relationship with TANG and DIV at the same significant level. LEV being one of the control variables in this study shows positive effects with no significantly relationship with TANG and FAGE. However, LEV has significant negative relationship with DIV at the $1 \%$ of significance level. TANG is not significantly relationship with FAGE and also shows a negative sign. However, DIV have a significant negative relationship with TANG at $1 \%$ level of significance. Lastly, FAGE neither have positive nor significant relationship with the DIV.

\section{Regression Results}

Table 3: Summary of Panel Data Analysis

\begin{tabular}{|l|l|c|c|}
\hline & & Model 1 & Model 2 \\
\hline C & Coefficient & -7.5383 & -7.9847 \\
& T-statistic & -12.8585 & -15.0323 \\
& Probability & 0.0000 & 0.0000 \\
\hline ETR in model 1 / & Coefficient & $0.0629^{* *}$ & -0.0865 \\
BTDs in model 2 & T-statistic & 2.0277 & -0.2554 \\
& Probability & 0.0431 & 0.7985 \\
\hline FSIZE & Coefficient & -0.3533 & -0.0424 \\
& T-statistic & -0.9074 & -0.1183 \\
& Probability & 0.3646 & 0.9059 \\
\hline LEV & Coefficient & $-0.2052^{* * *}$ & $-0.2423^{* * *}$ \\
& T-statistic & -7.4918 & -9.7679 \\
& Probability & 0.0000 & 0.0000 \\
\hline TANG & Coefficient & $-0.0647 * * *$ & $-0.0509 * *$ \\
& T-statistic & -2.8294 & -2.3827 \\
& Probability & 0.0048 & 0.0175 \\
\hline FAGE & Coefficient & $-0.2187 * * *$ & $-0.2310^{* * *}$ \\
& T-statistic & -4.3818 & -5.2485 \\
& Probability & 0.0000 & 0.0000 \\
\hline DIV & Coefficient & $-0.1077^{* * *}$ & $-0.0857^{* * *}$ \\
& F-statistics & -5.2335 & -4.6407 \\
& T-statistic & 0.0000 & 0.0000 \\
\hline & Probability & 0.1691 & 0.2045 \\
\hline \multicolumn{2}{|c|}{ R-squared } & 0.1602 & 0.1970 \\
\hline & R-squared & $0.0000^{* * *}$ & 27.2511 \\
\hline & & $0.0000^{* * *}$ \\
\hline
\end{tabular}

$* * *$. Correlation is significant at the 0.01 level (1-tailed)., **. Correlation is significant at the 0.05 level (1-tailed).*. Correlation is significant at the 0.10 level (1-tailed). 
Based on Table 3, the overall result in model 1 shows that ETR has a significant positive relationship with firm value at $5 \%$. The coefficient for ETR is 0.0629 . ETR has inverse relationship of tax planning. Higher ETR means lower of tax planning. The result indicates that firm with less tax planning has higher its firm value. This result consistent with Desai and Hines (2002), Wang (2010), and Chen et al. (2010), that found out that tax planning has significant negative relationship with firm value. Firms with less tax planning activities in its routine may signal investors that the company is much more transparent in publishing their financial information, causing investors to have more interest and confidence to invest in such company. However, in the model 2 the BTDs has negative effect with no significant relationship with firm value. BTDs maybe is not good tax planning proxy to determine firm value.

In relation to control variable and firm value, the first control variable which is FSIZE has insignificant negative relationship with firm value in both models. Those firms that are larger in size in terms of asset have lower firm value than firms that are smaller in size. According to Lee (2009) and Josson (2007) in their prior research said that smaller firms are expected to be financially flexible and can have better profitability. Also, according to Hall and Weiss et al (1969) they found that both firm size and profitability have negative relationship. The next control variable is LEV which has significant negative relationship with firm value at $1 \%$. It is consistent with result found Rajan and Zingales (1995). Firms with high leverage amount can easily involve in liquidation if they are not able to generate sufficient cash flow to finance the firm's expenses.

The third control variables in this study is that TANG. TANG has a significant a positive relationship with firm value at $1 \%$ in model 1 and $5 \%$ in model 2 . Muritula (2012) point out that the negative relation due to firms do not involve in manufacturing are not much benefit asset tangibility in their business environment. There are certain prior researches that agree on asset structure do not have any effect on the firm value (Okwo et.al, 2012; Setiadharma et.al, 2017). The next is relationship between FAGE with firm value. The results show that FAGE is significant negative relationship with firm value in both models at $1 \%$. Firms' that are aging from year to year are facing crucial times to be adapted to new modernising in the economy. This can be further emphasised with the research prior done by Loreder and Waelchili (2010), which states that firm age and firm performance are inversely related.

Finally, DIV has a significant positive relationship with firm value at $1 \%$. Hussainet et al. (2011) have conducted a research before regarding the relationship between dividend policy and variation in share price in the British Stock Market. The findings later reveal that dividend payout has negative relationship with share price change, which means that it also has negative impact on firm value.

\section{Conclusion and Implication of the Study}

The main objective of this research is to determine how tax planning can influence firm value. This study also aim to determine the relationship of firm's characteristics such as firm size, leverage, asset tangibility, firm age and dividend on firm value. As an overall, tax planning measure by ETR has significant relationship with firm value. Firms with less tax planning activities in their routine may signal investors that the company is much more transparent in publishing their financial information, causing investors to have more interest and confidence to invest in such company. BTDs as another proxy of tax planning has no significant relationship with firm value. BTDs maybe is not good tax 
planning proxy to determine firm value. This suggest that ETR proxy is suitable to determine firm value rather than BTDs. Most of our control variables such as leverage, asset tangibility, firm age and dividend have negative relationship with firm value.

There are several important implications of this study. First, this study has enabled to provide more information about the extent of understanding towards tax planning and firm value in Malaysia context. Furthermore, this study also provided several variables that can have influence on the firm value. As discussed in the result obtained from the regression reflects that tax planning or ETR has significant and positive relationship with firm value, while BTDs has insignificant negative relationship with firm value. Therefore, firms with less tax planning may signal to investors the firms have better corporate governance compare than firms that engage aggressive tax planning.

The limitation in conducting this research is that the study only included two tax planning proxies which are ETR and BTDs independent variable and five control variables are firm's size, leverage, asset tangibility, firm age and dividend. In reality, there are still many other factors that can determine firm value. Researcher may also expand their independents as well as control variables choices in testing their impact on firm value. This might increase the significance of result obtained. For future research, this study recommends that this research should be expanded by using more sample size from a longer time frame of research.

\section{Acknowledgment}

This research gratefully acknowledges the assistance of Universiti Malaysia Sarawak by giving Myra Grant Scheme [F01/SpMYRA/1681/2018].

\section{References}

Abdul-Wahab, N. S. (2010). Tax planning and corporate governance: Effect on shareholders' valuation. Unpublished PhD thesis, University of Southampton, UK. Retrieved from https://eprints.soton.ac.uk/162801/

Abdul-Wahab, N. S. and K. Holland (2012). Tax planning, corporate governance and firm value. British Accounting Review, 44 (2), 111-124.

Chen, S., Chen, X., Chen, Q. \& Shevlin, T. (2013). Are family firms more tax aggressive than non-family firms? The Journal of Financial Economics, 95(1), 41-61.

Desai, M.A., and Dharmapala, D. (2005). Corporate tax avoidance and firm value. National Bureau of Economic Research, Working Paper No. 11242.

Desai, M. A., \& Dharmapala, D. (2009). Corporate tax avoidance and firm value. The Review of Economics and Statistics, 91(3), 537-546.

Desai, M., \& J. Hines (2002). Expectations and expatriations: Tracing the causes and consequence of corporate inversions, National Tax Journal, 55(3), 409-440.

Ftouhi, K., Ayed, A., \& Zemzem, A. (2014). Tax planning and firm value: Evidence from European companies, International Journal Economics and Strategic Management of Business Process. 2nd International Conference on Business, Economics, Marketing and Management Research (BEMM'14), 4, 73-78.

Hall, M. \& L. Weiss (1967). Firm size and profitability, The Review of Economics and Statistics, 49(3), 319-331. 
INTERNATIONAL JOURNAL OF ACADEMIC RESEARCH IN BUSINESS AND SOCIAL SCIENCES

Vol. 8, No. 11, Nov, 2018, E-ISSN: 2222-6990 C 2018 HRMARS

Hanlon, M., \& Heitzman, S. (2010). A review of tax research, Journal of Accounting and Economics, 50(2), 127-178.

Hanlon, M., S. K. Laplante, \& T. Shevlin. (2005). Evidence for the possible information loss of conforming book income and taxable income. Journal of Law and Economics, 48(2), 407-442.

Hussainet, K., Mgbame, C.O., Aruoriwo, M.C.M. (2011). Dividend policy and share price volatility: UK evidence." The Journal of Risk Finance, 12(1), 57-68.

Lee, J. (2009). Does size matter in firm performance? Evidence from US Public Firms." International Journal of the Economics of Business, 16(2), 189-203.

Loderer, C. and U. Waelchli (2010). Firm age and performance, Munich Personal RePEc Archive, 1-52.

Martinez, A. L. and L. B. Ronconi (2013). "The informativeness of taxable income and book income before and after the adoption of IFRS in Brazil." Business Management Dynamics, 3(5), 51-63.

Morey, M., Gottesman, A., Baker, E. \& Godridge, B. (2009). Does better corporate governance result in higher valuations in emerging markets? Journal of Banking and Finance, 33(2), 254-262.

Okwo, IM., Okelue, UD., \& Nweze, A.U. (2012). Investment in fixed assets and firm profitability: Evidence from the Nigerian brewery industry. European Journal of Business and Management, 4(20), 10-17.

Premuroso, R. (2008). An analysis of voluntary annual report disclosures of outsourcing: Determinants and firm performance. Thesis for the degree of Doctor of Philosophy, Florida Atlantic University, Florida U.S. Retrieved from http://search.proquest.com/docview/304568419/fulltextPDF/139BBA67CC33A67696D/1?accou ntid=42599.

Rajan, R. G. and L. Zingales (1995). What do we know about capital structure? Some evidence from international data, Journal of Finance, 50(5), 1421-1460.

Setiadharma, S., \& Machali, M. (2017). The effect of asset structure and firm size on firm value with capital structure as intervening variable, Journal of Business and Financial Affairs, 6(4), DOI: 10.4172/2167-0234.1000298

Soufiene A., Khoula A., \& Mohamed Ali O. (2016). Tax optimization and the firm's value: Evidence from the Tunisian context, Borsa Istanbul Review, 16(3), 177 - 184.

Spence M. (1974), Market signaling: informational transfer in hiring and related processes, Cambridge: Harvard University Press.

Wang, T. X. (2010). Tax avoidance, corporate transparency, and firms value. Retrieved 2013, from http://ssrn.com.

Wilson, R. (2009). An examination of corporate tax shelter participants, The Accounting Review, 84 (3), 969-999. 